\title{
Experimental study on Qizhu formula for modulating survivin, an inhibitor of apoptosis, in MGC-803 gastric cancer cells
}

\author{
HAO WEN $^{1 *}$, XIAOHUA WANG ${ }^{1 *}$ and ZHAOWEI SHAN ${ }^{2}$ \\ ${ }^{1}$ Institute of Digestive Endoscopy and Medical Center for Digestive Diseases, \\ The Second Affiliated Hospital of Nanjing Medical University, Nanjing, Jiangsu 210011; \\ ${ }^{2}$ Institute of Digestive Diseases, Jiangsu Province Hospital of TCM, Nanjing, Jiangsu 210029, P.R. China
}

Received October 24, 2013; Accepted February 6, 2014

DOI: $10.3892 / \mathrm{mco} .2014 .268$

\begin{abstract}
The aim of this study was to investigate the mechanism of action of Qizhu formula, a Chinese medicinal empirical formula, in modulating the action of survivin, an inhibitor of apoptosis, in MGC-803 gastric cancer cells. Western blot analysis and reverse transcription-polymerase chain reaction (RT-PCR) were applied to detect the effect of varying concentrations of Qizhu formula in the modulation of the expression of survivin in MGC-803 human gastric adenocarcinoma cells. The western blot analysis results demonstrated that Qizhu formula exerted no significant effects on the protein expression of the $\beta$-actin housekeeping gene, whereas it exerted a significant inhibitory effect on the protein expression of the apoptosis-related survivin gene at concentrations of $250 \mu \mathrm{g} / \mathrm{ml}$ and, particularly, $500 \mu \mathrm{g} / \mathrm{ml}$. RT-PCR was used to detect the effect of Qizhu formula on survivin mRNA in MGC-803 human gastric adenocarcinoma cells. The ratio of survivin/ $\beta$-actin in the $0.1 \%$ dimethylsulfoxide and the 125,250 and $500 \mu \mathrm{g} / \mathrm{ml}$ groups of Qizhu formula was 0.4543 , $0.4025,0.2415$ and 0.2235 , respectively. Therefore, Qizhu formula exerted a distinct inhibitory effect on the mRNA expression of survivin in MGC-803 cells in a dose-dependent manner. In conclusion, Qizhu formula may modulate the apoptosis of MGC-803 human gastric adenocarcinoma cells, which is associated with the downregulation of survivin mRNA and protein expression.
\end{abstract}

\section{Introduction}

Gastric cancer is the most common gastrointestinal cancer, with the highest morbidity and mortality rates in China,

Correspondence to: Dr Xiaohua Wang, Institute of Digestive Endoscopy and Medical Center for Digestive Diseases, The Second Affiliated Hospital of Nanjing Medical University, 121 Jiangjiayuan Road, Nanjing, Jiangsu 210000, P.R. China

E-mail: wxhua1899@163.com

*Contributed equally

Key words: Qizhu formula, MGC-803 gastric cancer cells, survivin ranking second in the incidence of malignant tumors worldwide. Therefore, novel, more effective therapeutic options are required for the prevention and treatment of gastric cancer.

The occurrence and development of gastric cancer is a complicated, multistage and multifactorial process. An imbalance between cell apoptosis and proliferation is a key reason resulting in excessive proliferation of tumor cells. Survivin, which was screened and separated from the human genomic library by Ambrosini et al (1) by means of effector cell protease receptor- 1 cDNA, is a novel member of the inhibitor of apoptosis (IAP) family and a bifunctional protein that may inhibit cell apoptosis and regulate cell division. Survivin is highly expressed in embryonic and developing fetal tissues, but it is almost absent from the terminally differentiated tissues of normal adults, whereas it is selectively expressed in tumors. Survivin expression was previously detected in colon, gastric, esophageal and non-small-cell lung cancers (2-5) and a previous study indicated that survivin is highly expressed in gastric cancer tissues, but is almost absent from the normal tissues surrounding gastric cancer (6). However, Yao et al (7) detected survivin expression in gastric adenocarcinoma using the immunohistochemical streptavidin-peroxidase method and the results demonstrated that the positive expression rate of survivin in the primary focus of gastric cancer, metastatic cancer cells of lymph nodes and basal germinal layer cells of normal glands were 49.2, 64.0, and $17.5 \%$, respectively. Therefore, further investigation into the expression of survivin in tumor cells is required to elucidate the mechanisms underlying the occurrence and development of gastric cancer.

The majority of gastric cancers are middle- to advanced-stage at diagnosis and exhibit a low remission rate with chemotherapy. The anticancer role of traditional Chinese medicine (TCM) is under ongoing investigation in the medical field. In TCM, gastric cancer belongs to the classification of 'sick', 'dysphagia', 'stomachache' and 'accumulation' disease. Qizhu, an empirical formula for gastrointestinal tumors, has been subjected to numerous years of clinical research. Our earlier study (8) demonstrated that the Qizhu formula was able to inhibit the expression of telomerase and its related genes in MGC-803 gastric cancer cells.

In the present study, the effect of Qizhu on the downregulation of survivin protein and mRNA expression in MGC-803 human gastric adenocarcinoma cells was investigated by 
western blot analysis and reverse transcription-polymerase chain reaction (RT-PCR), with the aim to further demonstrate the induction of gastric cancer cell apoptosis by Qizhu and provide reliable experimental evidence regarding multitargeted treatment and application of TCM compounds in the treatment of gastric cancer.

\section{Materials and methods}

Tumor strain. The MGC-803 human gastric cancer cells were purchased from Nanjing Kaiteng Technological Corporation (Nanjing, China) and preserved by subculturing.

Drugs. Qizhu formula crude extracts (referred to as Qizhu formula hereafter) were purchased from Nanjing Zhongshan Pharmaceutical Factory (Nanjing, China). Qizhu formula consists of Zhihuangqi (Radix Astragali Praeparata cum Melle), Yuzhu (Rhizoma Polygonati Odorati), Fabanxia (Rhizoma Pinelliae Praeparatum), Shengyiyiren (Semen Coicis, raw), Xianhecao (Herba Agrimoniae), Ezhu (Rhizoma Curcumae) and Baihuasheshecao (Herba Hedyotis Diffusae). All the compounds in the formula were identified by TCM Identification Teaching and Research Section of Nanjing University of Chinese Medicine and conformed to the national pharmacopoeia criterion. Steam distillation was applied to extract zedoary oil, with $11.25 \mathrm{~g}$ extracted from $500 \mathrm{~g}$ of crude Ezhu, yielding $11.25 \mathrm{ml}$, for a yield of $2.25 \%$, namely $1 \mathrm{~g}=1 \mathrm{ml}$. The extracted residual Ezhu liquid was mixed with other crude drugs and the crude drugs were then extracted by poaching and alcohol precipitation. A total of $480.5 \mathrm{~g}$ crude extracts (dry extracts, $496.25 \mathrm{~g}+$ zedoary oil, $11.25 \mathrm{~g}$ ) was collected from $4,500 \mathrm{~g}$ of crude drugs, for a yield of $10.68 \%(480.5 / 4,500)$.

\section{Reagents}

Western blotting. Methanol, $200 \mathrm{ml} 10 \mathrm{X}$ blotting buffer, 1,400 $\mathrm{ml}$ deionized water and Coomassie brilliant blue $\mathrm{G}_{250}$ were collected for the western blotting procedure. First, $20 \mathrm{mg}$ of Coomassie brilliant blue $\mathrm{G}_{250}$ were dissolved into $10 \mathrm{ml}$ of $95 \%$ alcohol, followed by the addition of $20 \mathrm{ml} \mathrm{H}_{3} \mathrm{PO}_{4}$ and deionized water to a final volume of $200 \mathrm{ml}$. The mixture was filtered using filter paper and stored at $4^{\circ} \mathrm{C}$. Subsequently, $0.05 \mathrm{~g}$ bovine serum albumin (BSA) were dissolved in $100 \mathrm{ml}$ of double-distilled water $(0.5 \mathrm{mg} / \mathrm{ml})$ and stored at $4^{\circ} \mathrm{C}$. Finally, $0.01742 \mathrm{~g}$ phenylmethanesulfonyl fluoride (PMSF) were dissolved in $1 \mathrm{ml}$ of isopropanol $(100 \mathrm{mM})$, subpackaged and stored at $-20^{\circ} \mathrm{C}$. Acrylamide and ammonium persulfate were purchased from Longxi Chemical Company (Nanjing, China), tetramethylethylenediamine was obtained from American Amresco Co. (Solon, OH, USA) and horseradish peroxide solutions $A$ and $B$ were purchased from Beijing ZSGB-Biotechnology Co., Ltd. (Beijing, China).

$R T-P C R$. TRIzol (DP-405) was purchased from Beijing Tianwei Time Technology Co., Ltd. (Beijing, China), general RT-PCR kits (20 reactions) were obtained from Beijing Dingguo Biotechnology Co.,Ltd. (Beijing, China) and synthetic primers of survivin and $\beta$-actin genes were obtained from Shanghai Sangon Biotech Service Co., Ltd. (Shanghai, China). The TRIzol kits were provided by Tianyao Time Company (Tianjin, China) and diethyl pyrocarbonate was obtained from American Amresco Co. Pure chloroform, isopropanol and ethanol were all analyzed by the Longxi Chemical Company and agarose was obtained from Oxoid Limited (Hampshire, UK).

Main experimental apparatus. A laminar flow hood was obtained from Suzhou Purification Equipment Factory (Suzhou, China); a Forman $3111 \mathrm{CO}_{2}$ incubator was purchased from (Thermoscientific, West Palm Beach, FL, USA); a 550 enzyme-linked immunoassay detector was obtained from Bio-Rad Laboratories (Hercules, CA, USA); an LDZ5-2 medical centrifuge was purchased from Beijing Medical Centrifuge Factory (Beijing, China); a UV-2450 ultraviolet spectrophotometer was obtained from Shimadzu Co. (Milton Keynes, UK); a PHS-3C Precision pH meter was purchased from Shanghai Torpedo-Magnetic Instrument Plant (Shanghai, China); an FAZ104 electronic balance was obtained from Meigele Hardware Co., Ltd. (Guangzhou, China); a 101AS-3 stainless steel digital electrothermal air dry oven was purchased from Shanghai Shengxin Scientific Instrument Co., Ltd. (Shanghai, China); a YXQ-CS-30L double-layer stainless vertical sterilizer was obtained from the Medical Equipment Factory of Shanghai Boxun Industrial Co., Ltd. (Shanghai, China); a WD-940153 horizontal shaker was purchased from Beijing Liuyi Instrument Plant (Beijing, China); an XSZ-O2 inverted metallographic microscope was obtained from Chongqing Optical Instrument Plant (Chongqing, China); a PTC-100 PCR amplifier was purchased from MJ Reserach Inc. (Waltham, MA, USA); a SHO 3014 tabletop high-speed refrigerated centrifuge was obtained from Eppendorf (Hamburg, Germany); a Mini-PROTEAN vertical electrotransfer chamber was purchased from Bio-Rad Laboratories; and an FR-980 biological electrophoresis image analysis system was obtained from Shanghai Furi Technology Co., Ltd (Shanghai, China).

Assessment of Qizhu formula effect on survivin protein expression in MGC-803 cells by western blot analysis

Grouping. A negative control group, a dimethylsulfoxide (DMSO) solvent control group and two medication groups with different concentrations of Qizhu formula (250 and $500 \mu \mathrm{g} / \mathrm{ml})$ were set up.

Methods. The MGC-803 cells were first cultured to a certain concentration. Four 10-ml culture flasks were then inoculated with $2 \times 10^{6}$ cells and placed in a $5 \% \mathrm{CO}_{2}$ incubator for $24 \mathrm{~h}$ at $37^{\circ} \mathrm{C}$. Subsequently, a negative control group, a $0.1 \%$ DMSO solvent control group and two medication groups with different concentrations of Qizhu formula $(250$ and $500 \mu \mathrm{g} / \mathrm{ml})$ were set up. Finally, $10 \mathrm{ml}$ of the cultured cells were added to each of the four groups and placed in a $5 \% \mathrm{CO}_{2}$ incubator at $37^{\circ} \mathrm{C}$ for $24 \mathrm{~h}$.

Cell collection. Cell scraping paper was used to collect $10 \mathrm{ml}$ of cells in each group. The cells were centrifuged for $5 \mathrm{~min}$ at $352 \mathrm{xg}$, followed by the addition of $1 \mathrm{ml} \mathrm{PBS}$ to transfer the centrifuged cells to Eppendorf tubes and the mixture was centrifuged at $1,570 x g$ for $1 \mathrm{~min}$. The supernatant was then removed, the cells were washed again with PBS, beakers were prepared and tap water was added and heated to $95^{\circ} \mathrm{C}$. Furthermore, $500 \mu 1$ of lysis buffer were freshly prepared (497 $\mu 1$ lysis buffer, $2.5 \mu 1$ dithiothreitol and $0.5 \mu 1 \mathrm{PMSF})$. 
Cell lysis. Lysis buffer (110 $\mu \mathrm{l})$ was added to each group to create a cell suspension and placed on ice for $30 \mathrm{~min}$. A separation gel and a stacking gel were then prepared. Following lysis, the cells were centrifuged at 3,070xg for $10 \mathrm{~min}$, the supernatant was absorbed and another 1.5-ml Eppendorf tube was prepared to measure the protein concentration and conduct protein quantification. Finally, equal amounts of protein were collected from each sample, $10 \mu \mathrm{l}$ lysis buffer and $20 \mu \mathrm{l}$ $2 \mathrm{X}$ sample buffer were added and the solution was incubated at $95^{\circ} \mathrm{C}$ for $5 \mathrm{~min}$. The electrophoresis $10 \mathrm{X}$ running buffer was diluted to $1 \mathrm{X}$, the samples were placed on ice for $5 \mathrm{~min}$, centrifuged at 1,570xg for $1 \mathrm{~min}$ and the supernatant was absorbed to prevent trailing. The samples were placed in loading buffer and subjected to sodium dodecyl sulfate-polyacrylamide gel electrophoresis at $80 \mathrm{~V}$ for $2 \mathrm{~h}$.

Electrotransfer membranes. In total, $500 \mathrm{ml} 1 \mathrm{X}$ blotting buffer (100 ml methanol, $50 \mathrm{ml}$ 10X blotting buffer and $350 \mathrm{ml}$ water) were freshly prepared. The gel was cut into $5.5 \times 5 \mathrm{~cm}$ pieces, placed in $1 \mathrm{X}$ blotting buffer and marked; two pieces of the PVDF mebrane were sheared into $6.5 \times 6 \mathrm{~cm}$ pieces and activated in methanol over $5 \mathrm{~min}$. Eight filter papers with two pieces on one side were then placed into $1 \mathrm{X}$ blotting buffer to siphon, the PVDF was removed from the methanol, washed once with distilled water and placed into $1 \mathrm{X}$ blotting buffer with the gel. In total, four sponges were prepared and soaked in $1 \mathrm{X}$ blotting buffer; subsequently, the sponges, two flat pieces of filter paper, the gel (peripheral absorption-desorption $1 \mathrm{X}$ blotting buffer) and the flat membranes (moistened with $1 \mathrm{X}$ blotting buffer) were placed on a wet-rotating device in turn to compress the filter papers and sponges, followed by placement in a $100 \mathrm{~V}$ vertical electrophoresis chamber for $1 \mathrm{~h}$. The chamber was filled with $1 \mathrm{X}$ blotting buffer and an ice box was placed along its side.

Protein detection. The capsular membranes were placed into two small containers filled with blocking buffer at $4^{\circ} \mathrm{C}$ for $8 \mathrm{~h}$ to block the non-reactive sites on the membranes in order to inhibit the non-specific absorption of antibodies. The primary goat polyclonal $\beta$-actin (1:500) and rabbit polyclonal survivin (1:500) antibodies (Santa Cruz Biotechnology Inc., Santa Cruz, CA) were then diluted with blocking buffer, the opening was sealed with film and the table was agitated horizontally for $1 \mathrm{~h}$ to combine the antigens and antibodies. The membranes were washed three times with Tris-buffered saline (TBS) for 15 min each time, the secondary donkey antirabbit antibodies (1:5,000; Santa Cruz Biotechnology Inc.) with horseradish peroxidase were added and the mixture was diluted with blocking buffer. The opening was sealed with film and the table was agitated horizontally for $45 \mathrm{~min}$. Finally, the samples were washed three times with TBS for 15 min per wash and developed in a dark room by X-ray radiography.

Assessment of Qizhu formula effect on survivin protein expression in MGC-803 cells using RT-PCR

Grouping. A $0.1 \%$ DMSO group and three medication groups with different concentrations of Qizhu formula (125, 250 and $500 \mu \mathrm{g} / \mathrm{ml}$ ) were set up.

\section{Methods}

Cell collection. First, the MGC-803 cells were collected at the logarithmic phase and added to four $30-\mathrm{cm}^{2}$ Petri dishes, with $4.5 \times 10^{6}$ cells per dish. The cells were placed in a $5 \% \mathrm{CO}_{2}$ incubator at $37^{\circ} \mathrm{C}$ for $24 \mathrm{~h}$, followed by the addition of $6 \mathrm{ml}$ $0.1 \%$ DMSO, 125250 , or $500 \mu \mathrm{g} / \mathrm{ml}$ Qizhu formula and placement in a $5 \% \mathrm{CO}_{2}$ incubator at $37^{\circ} \mathrm{C}$ for $24 \mathrm{~h}$.

Total MGC-803 cell RNA extraction. TRIzol one-step extraction was performed according to the manufacturer's instructions as follows: First, the supernatant was removed, $3 \mathrm{ml}$ TRIzol $\left(1 \mathrm{ml} / 10 \mathrm{~cm}^{2}\right)$ were added to each Petri dish, the homogenate samples were repeatedly absorbed and blown 20 times with a $1-\mathrm{ml}$ spearhead and the sample was left to rest for $5 \mathrm{~min}$ at $15^{\circ} \mathrm{C}$. Second, the supernatant was obtained after a 10 -min centrifugation at $10,000 \times \mathrm{g}$ at $4^{\circ} \mathrm{C}$; the sample was then vigorously agitated for $15 \mathrm{sec}$ following the addition of $0.6 \mathrm{ml}$ trichloromethane $\left(0.2 \mathrm{ml} \mathrm{CHCl}_{3} / 1 \mathrm{ml}\right.$ TRIzol $)$ and was kept for $3 \mathrm{~min}$ at room temperature. Third, the sample was centrifuged for $15 \mathrm{~min}$ at $10,000 \mathrm{x} \mathrm{g}$ at $4^{\circ} \mathrm{C}$, the upper layer of fluid was transferred to another dry Eppendorf tube, $1.5 \mathrm{ml}$ of isopropanol ( $0.5 \mathrm{ml}$ isopropanol $/ 1 \mathrm{ml}$ TRIzol) were added, the sample was kept for $10 \mathrm{~min}$ at room temperature after blending and centrifuged for $10 \mathrm{~min}$ at $10,000 \mathrm{x} \mathrm{g}$ at $4^{\circ} \mathrm{C}$. Fourth, the supernatant was discarded, the sediment was removed, $3 \mathrm{ml} \mathrm{75 \%}$ alcohol ( $1 \mathrm{ml} 75 \%$ alcohol/1 $\mathrm{ml}$ TRIzol) were added and the solution was blended. The supernatant was then discarded by absorption with a spearhead following centrifugation for $5 \mathrm{~min}$ at $<7,500 \mathrm{xg}$ at $4^{\circ} \mathrm{C}$ and the sample was dried for 5-10 min at room temperature. Fifth, $20 \mu \mathrm{l}$ water without RNA enzymes were added and the pellet was dissolved using the blow and beat of the spearhead. The optical density (OD) at 260 and $280 \mathrm{~nm}$ was measured using an ultraviolet spectrophotometer following addition of water without RNA enzymes to $2 \mu \mathrm{l}$ RNA to a final volume of $1 \mathrm{ml}$. Finally, the RNA concentration was calculated according to the formula $\left[\left(\mathrm{OD}_{260 \mathrm{~nm}}-\mathrm{OD}_{\mathrm{H}_{2} \mathrm{O}}\right) \times \mathrm{H}_{2} \mathrm{O}(\mathrm{ml}) /\right.$ template $\left.(\mu \mathrm{l})\right]$ x $40 \mu \mathrm{g} / \mu \mathrm{l}$ and the RNA purity to $\mathrm{OD}_{260} / \mathrm{OD}_{280}$. The ranges of extracted RNA $\mathrm{OD}_{260} / \mathrm{OD}_{280}$ of $1.78-2.0$ were diluted to $1 \mu \mathrm{g} / \mu \mathrm{l}$ and kept at $-72^{\circ} \mathrm{C}$.

RT-PCR was performed according to the instructions of a general RT-PCR kit. Based on the primer design of the gene sequences provided by the gene pools, the primer sequences were as follows through Blast comparison: $\beta$-actin gene primer sequence: upstream, 5'-ATCATGTTTGAGACCTTCAACA-3' and downstream, 5'-CATCTCTTGCTCGAAGTCCA-3' with a product length of $318 \mathrm{bp}$; survivin gene primer sequence: upstream, 5'-CACCGCATCTCTACATTCAAG-3' $(97,118)$ and downstream, 5'-GAAGCAGCCACTGTTACCAG-3' (681,700) with an amplified fragment length of $612 \mathrm{bp}$.

$R T$ reaction. Total RNA $(5 \mu \mathrm{g})$ was transferred to a $0.2-\mathrm{ml}$ centrifuge tube, maintained at $65^{\circ} \mathrm{C}$ for $10 \mathrm{~min}$ and placed in an ice bath following centrifugation for several seconds. We then prepared a $20 \mu \mathrm{l}$ reactive system of table preparation in the centrifugal tube: $1 \mu \mathrm{l}$ solution A [random primer (RP)], $1 \mu \mathrm{l}$ solution B (dNTPs), $4 \mu$ l solution D (5X RT buffer), $1 \mu$ l solution $\mathrm{E}$ (enzymatic mixed solution), $5 \mu \mathrm{l}$ RNA and mRNA samples, followed by the addition of $8 \mu \mathrm{l}$ solution $\mathrm{G}$ to the final volume of $20 \mu \mathrm{l}$. The sample was left to rest for $10 \mathrm{~min}$ at room temperature and the temperature was maintained for $30 \mathrm{~min}$ at $37^{\circ} \mathrm{C}, 5 \mathrm{~min}$ at $95^{\circ} \mathrm{C}$ and $4^{\circ} \mathrm{C}$ for $5 \mathrm{~min}$, respectively. The samples were immediately used or stored at $-20^{\circ} \mathrm{C}$.

$P C R$ reaction. The 50- $\mu 1$ PCR sample was prepared as follows: $4 \mu \mathrm{l}$ RT reactive products, $4.5 \mu \mathrm{l}$ solution F (10X PCR buffer), $1 \mu$ l solution B (dNTPs), 50 pmol upstream primers, 


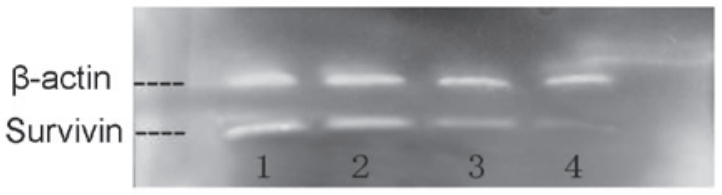

Figure 1. Protein expression of $\beta$-actin and survivin in MGC-803 human gastric adenocarcinoma cells. Lane 1, negative control; lane 2, dimethylsulfoxide control; lane 3, $250 \mu \mathrm{g} / \mathrm{ml}$ Qizhu formula; and lane 4,500 $\mu \mathrm{g} / \mathrm{ml}$ Qizhu formula.

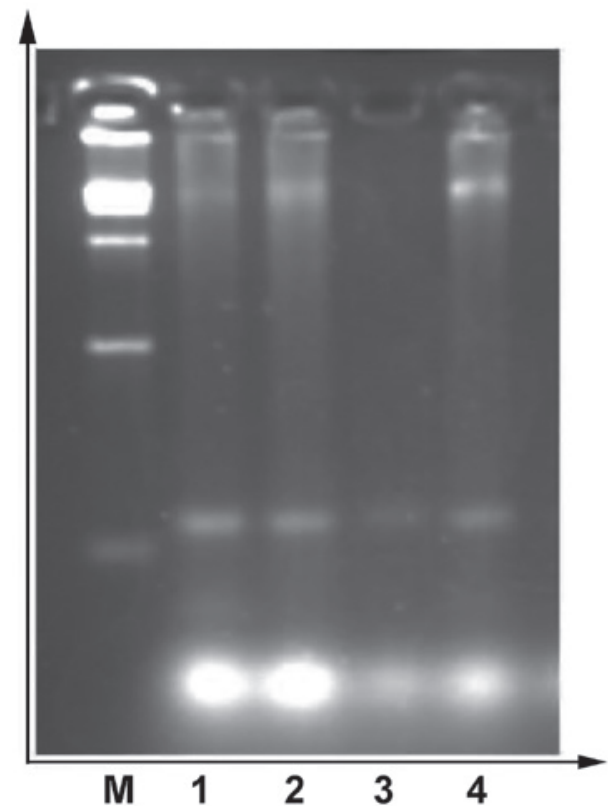

Figure 2. Functional electrophoretogram of the effect of Qizhu formula on survivin mRNA expression in MGC-803 human gastric adenocarcinoma cells. Lane M, marker; lane 1, 0.1\% dimethylsulfoxide; lane 2, $125 \mu \mathrm{g} / \mathrm{ml}$ Qizhu formula; lane 3, $250 \mu \mathrm{g} / \mathrm{ml}$ Qizhu formula; and lane 4, $500 \mu \mathrm{g} / \mathrm{ml}$ Qizhu formula.

50 pmol downstream primers, $1 \mu 1$ solution C (Taq enzyme) and solution $\mathrm{G}$ to a volume of $50 \mu \mathrm{l}$. A PCR amplifier was then added following centrifugation for several seconds and the result was finally observed using agarose gel electrophoresis. The amplification parameters were as follows: denaturation for $2 \mathrm{~min}$ at $94^{\circ} \mathrm{C}$ (denaturation at $94^{\circ} \mathrm{C}$ for $45 \mathrm{sec}$; renaturation at $55^{\circ} \mathrm{C}$ for $45 \mathrm{sec}$; extension at $72^{\circ} \mathrm{C}$ for $45 \mathrm{sec}$ ), amplification for 30 cycles, extension for $5 \mathrm{~min}$ at $72^{\circ} \mathrm{C}$ and storage at $4^{\circ} \mathrm{C}$.

Semi-qualitative agarose electrophoresis and analysis. First, ethidium bromide was added to $10 \mu 1$ of the PCR products and electrophoresis was conducted on a $2 \%$ agarose gel $(1 \mathrm{~h}$ at $80 \mathrm{~V})$. Images of the electrophoretogram were captured using an FR-980 biological electrophoresis image analysis system (Shanghai Furi Technology Co., Ltd., Shanghai, China) and the results were analyzed using SmartView analysis software (Everett, WA, USA). The survivin/ $\beta$-actin ratio of each sample was calculated using $\beta$-actin as an internal standard. A smaller ratio indicated a lower level of survivin mRNA expression.

\section{Results}

Experimental results of the Qizhu formula on survivin protein expression in MGC-803 cells with western blotting. A gray

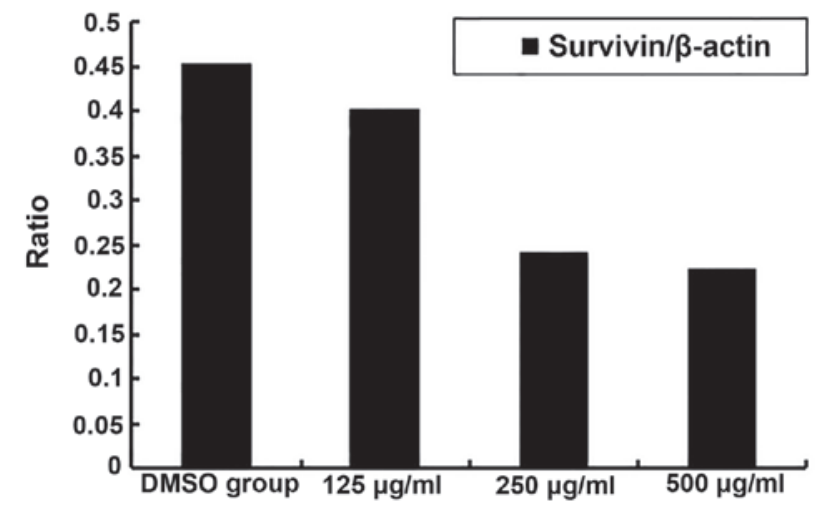

Figure 3. Efects of Qizhu formula on survivin mRNA expression in human MGC-803 gastric adenocarcinoma cells. DMSO, dimethylsulfoxide.

qualitative analysis of $\beta$-actin and survivin indicated that the Qizhu formula exerted no explicit effects on the protein expression of the housekeeping $\beta$-actin gene; however, it exerted a significant inhibitory effect on the protein expression of the apoptosis-related survivin gene at concentrations of $250 \mu \mathrm{g} / \mathrm{ml}$ and, particularly, $500 \mu \mathrm{g} / \mathrm{ml}$ (Fig. 1).

Experimental results of survivin $m R N A$ expression in $M G C-803$ cells with RT-PCR. The effect of Qizhu formula on survivin mRNA expression in MGC-803 human gastric adenocarcinoma cells is shown in Fig. 2. The ratios of survivin/ $\beta$-actin in the $0.1 \%$ DMSO group and in each of the Qizhu formula groups $(125,250$ and $500 \mu \mathrm{g} / \mathrm{ml})$ were 0.4543 , $0.4025,0.2415$, and 0.2235 , respectively (Fig. 3).

The Qizhu formula was shown to modulate the protein expression of survivin in MGC-803 human gastric adenocarcinoma cells, indicating that this formula acts by downregulating the inhibition of apoptosis of tumor cells. Additionally, Qizhu formula exerted a significant inhibitory effect on survivin mRNA expression in MGC-803 human gastric adenocarcinoma cells in a dose-dependent manner. These results further indicate that Qizhu formula may induce apoptosis of gastric cancer cells by downregulating IAP survivin mRNA expression.

\section{Discussion}

Cell proliferation and apoptosis are essential in maintaining body homeostasis. Tumor cells accelerate cell cycles and downregulate apoptosis-related genes using complex molecular mechanisms, consequently contributing to the malignant proliferation characteristics of tumors. Apoptosis is a key event in the process of tumor growth and tumor cells frequently exhibit defective apoptotic signal transduction pathways.

Previous studies indicated that the high expression of survivin, the most potent IAP currently identified and the smallest of the IAP family, is able to inhibit apoptosis induced by various apoptosis-stimulating factors, such as caspases. Wen et al (9) demonstrated that survivin expression in gastric cancer tissue was negatively associated with caspase- 3 expression, whereas the changes in the expression levels of caspase- 3 in gastric cancer tissues were correlated with the occurrence and development of gastric cancer, indicating that survivin 
exerts its inhibitory effect on cell apoptosis by inhibiting caspase-3, resulting in tumorigenesis and cancer progression.

Our earlier study (8) also indicated that Qizhu formula not only decreases telomerase activity in MGC-803 human gastric adenocarcinoma cells and protein expression of the telomerase-related hTERT gene, but it can also induce caspase-3, an apoptosis-related protease in its core position.

The present study demonstrated the ability of Qizhu formula to modulate protein and mRNA expression of the survivin gene in MGC-803 cells. The gray qualitative analysis of $\beta$-actin and survivin revealed that this formula exerted no explicit effects on the protein expression of the $\beta$-actin housekeeping gene, whereas it exerted a significant inhibitory effect on the protein expression of the apoptosis-related survivin gene at concentrations of $250 \mu \mathrm{g} / \mathrm{ml}$ and, particularly, $500 \mu \mathrm{g} / \mathrm{ml}$. RT-PCR was used to detect the effect of Qizhu formula on survivin mRNA expression in MGC-803 human gastric adenocarcinoma cells. The ratios of survivin $/ \beta$-actin in the $0.1 \%$ DMSO group and in each of the Qizhu formula groups $(125,250$ and $500 \mu \mathrm{g} / \mathrm{ml})$ were $0.4543,0.4025,0.2415$ and 0.2235 , respectively, indicating that Qizhu formula exerted a significant inhibitory effect on MGC-803 survivin mRNA expression in a dose-dependent manner. These results demonstrated that the Chinese medicinal Qizhu formula decreases protein and mRNA expression of the IAP survivin gene, which may represent an additional target pathway via which Qizhu formula intervenes in the process of tumor apoptosis and exerts its antitumor effects.

It was previously demonstrated that the Qizhu formula inhibits the telomerase proliferation of MGC-803 gastric cancer cells and induces caspase-3, an apoptosis-related protease, in the core position and decreases the protein and
mRNA expression of the IAP survivin gene (8). Therefore, it may be deduced that Qizhu formula intervenes in gastric cancer through multiple pathways, multiple targets and bidirectional regulation, which further provides objective evidence of the anticancer efficacy of this Chinese medicinal compound.

\section{References}

1. Ambrosini G, Adida C and Altieri DC: A novel anti-apoptosis gene, survivin, expressed in cancer and lymphoma. Nat Med 3: 917-921, 1997.

2. Liang QL, Wang BR and Li GH: DcR3 and survivin are highly expressed in colorectal carcinoma and closely correlated to its clinicopathologic parameters. J Zhejiang Univ Sci B 10: 675-682, 2009.

3. Hu ZD, Zhong MZ and Zhou HJ: Expression and significance of MMP-7 and survivin in gastric cancer. Cancer Res Prev Treat 39: $1349-1352,2012$

4. Hoffmann AC, Vallböhmer D, Grimminger P, et al: Preoperative survivin mRNA detection in peripheral blood is an independent predictor of outcome in esophageal carcinoma. Pharmacogenomics 11: 341-347, 2010.

5. Krepela E, Dankova P, Moravcikova E, et al: Increased expression of inhibitor of apoptosis proteins, survivin and XIAP, in non-small cell lung carcinoma. Int J Oncol 35: 1449-1462, 2009.

6. Meng H, Lu C, Mabuchi $\mathrm{H}$ and Tanigawa N: Prognostic significance and different properties of survivin splicing variants in gastric cancer. Cancer Lett 216: 147-155, 2004.

7. Yao XQ, Liu FK and Qi XP: Research on the correlation between survivin gene expression in gastric adenocarcinoma tissue and cell proliferation as well as apoptosis. Chin J Surg 42: 145-148, 2004 (In Chinese).

8. Wang XH and Shan ZW: Effects of Qizhu Formula on caspase-3 and telomerase proliferation and apoptosis in human gastric adenocarcinoma cells MGC-803. Chin J Integr Trad West Med Dig 14: 90-92, 2006 (In Chinese).

9. Wen YY and Liu BH: Functions of survivin gene and caspase-3 in the genesis of gastric cancer. Dig Surg 3: 415-418, 2004. 